\title{
Úton egy posztmodern, magyar tervezési paradigma felé, avagy társadalmi átalakulás a tervezői narratívában
}

A rendszerváltáskor elindult politikai decentralizáció, az információs technológiák fejlődése és az ezeknek köszönhető strukturális átalakulási folyamatok, a hazai tervezési kultúra közegét alapjaiban rajzolták át. Az így kialakult disszonancia a tervezés közege és módszertana között jól megfigyelhető válságot eredményezett a hazai tervezés gyakorlatában. A szerző a tervezés diszfunkcionális müködésének jelenséghalmazát a tervezés fogalmának a hibás értelmezésében diagnosztizálja. A posztmodern tervezési paradigmák közül választva bizonyítja ennek a fogalomnak az érzékenységét a tervezési kultúra változásaira és javasolja egy új társadalmi konszenzus létrehozását a tervezés fogalmáról és rendszeréről. A változás jellege alapján ezt a konszenzusépítést egy tanulási folyamatban azonosítja.

Kulcsszavak: tervezés elmélet, közpolitika, magyar posztmodern, építészet, tervezés kultúra, átalakulás, tanulási folyamat

\section{Szerzői információ:}

Csaba Ders

Építész, 2003-ban szerezte diplomáját a PTE PMMF múszaki karán, ugyanott készíti doktori diszszertációját. A 2006/2007-es tanévben Fulbright-ösztöndíjas vendégkutató volt a Columbia Egyetem várostervezési karán, jelenleg a University College London építészeti karán városfejlesztést és -tervezést tanul. Kíváncsi, szeret tanulni és tanítani. Kutatásaiban, írásaiban a világot az építészet szemszögéból, de a lehetố legtágabb perspektívában igyekszik szemlélni. Két egyszerú kérdést ismételget magának: 1. Mit tudunk ma a világról? 2. És mi köze van ennek az építészethez?

\section{Így hivatkozzon erre a cikkre:}

Csaba Ders. „Úton egy posztmodern, magyar tervezési paradigma felé, avagy társadalmi

átalakulás a tervezői narratívában.”

Információs Társadalom IX, 1. szám (2009): 74-80.

$=$ https://dx.doi.org/10.22503/inftars.IX.2009.1.8

A folyóiratban közölt müvek

a Creative Commons Nevezd meg! - Ne add el! - Így add tovább! 4.0

Nemzetközi Licenc feltételeinek megfelelően használhatók. 
Ders Csaba

\section{Úton egy posztmodern, magyar tervezési paradigma felé, avagy társadalmi átalakulás a tervezói narratívában \\ Utóirat egy manifesztumhoz}

Az építészeti nyelv szimbólumrendszere sokszínú tartalmi bővülésen ment keresztül a modern korszaka óta. 'Az „építészeti szavak” szimbólumainak változása azonban felveti magának a szimbólumrendszer, a „nyelvtan” változásának a kérdését is. Ebben a cikkben ezt a kérdést „mozgásban” fogom tárgyalni, megidézve azt a fejlődési folyamatot, amin gondolkodásmódom az elmúlt egy év során, a Manifesztum megjelenése óta keresztülment. Ugyanezt a témát ma már a tervezés jóval általánosabb fogalmi öszszefüggéseiben vizsgálom, azzal a kiegészítô céllal, hogy egy kicsit közelebb kerüljünk a rendszerváltás óta eltelt időszak változásainak megértéséhez.

Abban bízom, hogy az interdiszciplináris érdeklődésú olvasóközönség számára érdekesek és tanulságosak lehetnek ennek az igen súrú korszaknak az építészeti, tervezéselméleti narratívái. Nem titkoltan abban is bízom, hogy ez az írás talán hozzájárulhat a hídépítéshez a témával foglalkozó más tudományok múvelói és az építészek között.

2007 késố nyarán egy barátommal, a delfti múiszaki egyetem tanárával együtt nemzetközi workshopot szerveztünk építészhallgatóknak, az akkor még elókészítési fázisban levő Zsolnay kulturális negyedról. A szakmai esemény nem önmagában állt, megelőzte egy igen színvonalas szimpózium, amely a negyed fejlesztésének két egymással összefüggó́ kulcsfogalmát igyekezett tisztázni: ${ }^{3}$ konkrétan azt vizsgálta (én a konferencián sajnos nem vettem részt), hogy mit jelent a „kulturális alapú” kifejezés, és mit jelent a „városfejlesztés”.

A probléma mélységét akkor értjük meg, ha még azt is hozzáfúzöm, hogy a hazai városfejlesztési koncepciók eddig kizárólag központi források újraelosztására épültek, és a kultúra a közfelfogásban - és szomorú módon a kultúra menedzsereinek az értelmezésében is - csak közpénzekból finanszírozható, vagyis ellentmondás mutatkozik a kultúra mint városfejlesztési eróforrás felfogásában.

A szakmai kihívások azonban sajnos nem merülnek ki ennyiben, hiszen ma Magyarországon nincs nemzetközileg elfogadott értelemben vett városfejlesztési képzés, nincs olyan szakembergárda, amely hitelt érdemló módon képes lenne kezelni ezeket a dilemmákat. Ilyen szerepekben általában öt szakma képviselóit lehet látni:

' Ders Csaba: Néhány gondolat a szimbolikus rendszerek szerepéról az építészetben és általában a környezetalakítás kultúrájában. Informéciós Trársadalom, 2008/4. szám.

${ }^{2}$ http://flickr.com/photos/csabaders/

${ }^{3}$ http://www.epiteszforum.hu/node/3575 
1. Jogászokat, akik arra építik szakmai legitimitásukat, hogy sok esetben végsố soron közigazgatási kérdésekról van szó. (Ez azonban nyilvánvalóan elégtelen háttér egy sikeres városfejlesztési folyamat megtervezéséhez és lebonyolításához.)

2. Közgazdászokat, akiknek használható a tudásuk a gazdasági folyamatok sikeres irányításához, de nyilvánvalóan hasonlóan korlátozottan értelmezik a városfejlesztés fogalmát.

3. Építészeket, akik jellemzően a fizikai infrastruktúra fejlesztésével azonosítják a városfejlesztést. (Ez - az elóbbiekhez hasonlóan - szintén erôsen leegyszerúsített felfogása a problémáknak.)

4. Földrajztudósokat, akiknek az ismeretei talán a legkomplexebbek és legátfogóbbak ugyan, csakhogy a városfejlesztés sokkal inkább „mikro-”, mintsem „makroökonómiai" kérdés.

5. És végül, de nem utolsósorban, nagy ritkán településtervezókre bukkanunk, akiknek a profiljuk talán a legmegfelelóbb volna, de sajnos a mai decentralizált politikai és (ezt mint politikai strukturális jelzớt használom a modernre jellemzố centralizált struktúra ellentéteként... egyébként az átpolitizált is teljesen igaz, de az sajnos nem tervezéselméleti kategória) piaci alapú gazdasági városfejlesztési közeghez nekik sincsenek versenyképes szakmai ismereteik.

Egy tudománytörténész valószínúleg most elégedetten mosolyog, hiszen ez a szakmaikompetencia-zavar tipikus jele egy új tudományág születésének vagy egy régi átalakulásának. Egy változó világban ugyanis teljesen természetes, hogy az új kihívások új ismeretek megszerzését igénylik egy szakterület múvelôitól, és ez a tudás szerencsés esetben más szakmák területén már rendelkezésre is áll. Ez a helyzet szükségszerúen vezet a maihoz hasonló kompetenciaharcokhoz.

Egy egyetemi oktató szempontjából azonban mindez nagyszerúen kibontott problémahalmazt jelent, amely egyben tökéletes korrajz is a hazai városfejlesztés kihívásairól, továbbá nagyszerú alkalom arra, hogy a diákok alaposabban megismerhessék az építészeti tevékenység közegét, felismerhessék szakmai kompetenciájuk hiányosságait, röviden újrafogalmazhassák szakmai szerepüket egy drámai ütemben változó világban.

A bevezetóben említett workshop végül is olyan jól sikerült, hogy a két egyetemhez csatlakozott a Szent István Egyetem építészkara is, és a végén egy összegző tárlatban foglaltuk össze a probléma kibontásakor a diákok és tanáraik közös tapasztalatai. Úgy gondoltam, hogy ezek a kérdések az építésztársadalom egészét érintik. Ezért már a kezdetektól fogva igyekeztem a munkánkat láthatóvá tenni a szakmai érdeklődók számára. A tervbírálatok nyilvános szakmai viták keretében folytak, ${ }^{4}$ munkánk az Építốmúvészek Szövetségének támogatásával két hétig látható volt a Zsolnay-pályázatban érdekeltek számára, és végül afféle összegzésként a legnépszerúbb elektronikus építészeti lapban publikáltam a Manifesztumot.

Annak ellenére, hogy ennek a „szellemi provokációnak” nem sok visszhangja volt, az azóta eltelt közel egy év folyamán több fontos dolog is történt. Elôször is megindult egy új építészetpolitika kidolgozása, ${ }^{5}$ amelyben a Magyar Urbanisztikai Társaság delegáltjaként augusztusig jómagam is részt vehettem. Másrészt a hazai területfejlesztés

${ }^{4}$ A fotó-összefoglalót lásd itt: http://flickr.com/photos/csabaders/

${ }^{5}$ http://www.architectforum.hu/files/vitairat2.pdf 
eszköztára az Integrált Városfejlesztési Stratégia bevezetésével minóségi lépést tett a változás irányában. ${ }^{6}$ Mindkét esemény komoly elôrehaladást jelent, de az átalakulási folyamat még korántsem került nyugvópontra.

\section{Feladatok a tervezéselmélet képzeletbeli hallgatói számára ${ }^{7}$}

Planning is the organization of hopes.

(A tervezés a vágyak összehangolásának múvészete, vagy „a terv a remények szervezete”.)

Christopher Alexander ${ }^{8}$ (ford. Ders Csaba)

\section{Határozsuk meg, hogy Christopher Alexander mikor fogalmazhatta meg a tervezés fenti definícióját!}

Kétségtelenül a modern érett korszaka után járhatunk, hiszen a terv a valóságot már nem szigorúan tudományos nézốpontból szemléli, hanem valamiféle racionális-irracionális dichotómiával, olyan perspektívából, ahonnan a terv politikailag és társadalmilag alapjában véve neutrálisnak túnik. Ebben a definícióban azonban ennek éppen az ellenkezójéról van szó, hiszen a cél bizonyos produktív kompromisszum keresése a nagyon is szubjektív és sokszínúi társadalmi és politikai érdekek között. A tervezés folyamata és szereposztása is posztmodern paradigmára utal, hiszen a tervezố már nem a tervezéstudomány apostola, aki kinyilatkoztat, hanem sokkal inkább tervezôtárs, aki a felhasználókra mint partnerekre tekint, és igyekszik bevonni ôket egy közös utópia megfogalmazásába és megvalósításába. Bizonyosan nem haladtuk meg azonban a politikai gazdaságtan Castells és társai által újraértelmezett tervezési felfogását, hiszen az érdekegyeztetést Alexander nem a városteremtő erók rendszerébe beavatkozva igyekszik megvalósítani, hanem ezeket az eróket adottságként kezelve törekszik a Habermas sugallta „mindig lehetséges” kompromisszumra.

Ez a „kis” feladat szerintem a tervezés természetének talán a legfontosabb vonását teszi érzékelhetôvé, nevezetesen azt, hogy a tervezés fogalma és rendszere sem állandó. Elsố közelítésben úgy túnik, ez a fogalom csak egy adott társadalmi, politikai, gazdasági és kulturális kontextusban nyerhet értelmet. Ha jobban szemügyre vesszük, a rögtönzött válasz fel is fed egy sor markáns különbséget Alexander koncepciója és a referenciaként használt modern paradigma közege között.

A modernitás értékrendje a századforduló tudományos és múvészeti eredményei által sugallt „megismerhetố világ” racionalitására, míg Alexanderé a 60-as években ön-

${ }^{\circ}$ http://www.nfu.hu/integralt_varosfejlesztesi_strategiak_keszitese_tajekoztatas_a_mentori_segitsegn yujtas_igenybevetelerol

7 Indokolt „képzeletbeli” hallgatókról beszélni, hiszen Magyarországon - furcsa módon - nincs ilyen képzés. A tervezés tágabb összefüggéseiról itt elmondottakat nagyrészt a University College London interdiszciplináris építészeti karán ('The Bartlett) városfejlesztés-tervezés szakon folytatott tanulmányaim alapján fogalmaztam meg.

${ }^{8}$ Christopher Alexander fiatal korában nagy tehetséget mutatott a természettudományokhoz, matematikai és fizikai tanulmányai után azonban végül is ćpítészctct tanult, diplomáját ćs késöbb doktori fokozatát a Harvardon szerezte. 1963-tól a Berkeley építészeti tanszékénck a professzora, ugyanazon a karon, ahol Manucl Castells is tanít. Nem véletlenül rezonál egymásra Castells városfejlesztési víziója és Alexander építészeti koncepciója. 
tudatra ébredô társadalmi csoportok társadalmiigazságosság-víziójára épül. Az elóbbi egy politikailag centralizált struktúrára építve kinyilatkoztat, míg az utóbbi egy alapvetôen decentralizált közegben viszonylag nagyfokú autonómiával rendelkezô szereplók között igyekszik egy közös cél érdekében mediálni. Az egyik a központi források racionális újraelosztására törekszik, a másik viszont a piaci szereplók forrásait igyekszik mobilizálni egy érdekegyeztetési folyamat segítségével. Míg az első esetben a terv fốként a fizikai infrastruktúrára koncentrál, addig a másodikban a terv szerepe társadalmi konszenzus építése a fizikai infrastruktúra fejlesztéséról. Az összehasonlítás hosszasan folytatható volna: a lényeg az, hogy a két paradigmában a tervezés két különböző társadalmi vízió szerint, különböző szerepekben túnik fel, és más értékek alapján, más eszközökkel igyekszik alapvetôen más jellegư céljait elérni. Így tehát az túnik az egyetlen járható útnak a tervezés általános fogalmának megalkotásához, ha a tervezést társadalmi funkcióként értelmezzük, amely a közösségi források felhasználásával foglalkozik, és amelynek a jellemzói az adott társadalmi közeggel együtt változnak.

\section{A tervezés fogalmának társadalmi összefüggései}

Nemrég fejeztem be egy tanulmányt a modernitás kialakulásától napjainkig terjedô korszak jelentôsebb tervezési paradigmáiról," és mivel a szakirodalomban nem találtam általánosítható definíciót, egy kérdéssort használtam vezérfonalként. Úgy gondoltam, ezek a kérdések egyrészt lefedik azt a problémahalmazt, amelyre egy valamirevaló tervezési paradigmának válaszolnia kell, másrészt ezekból a válaszokból kirajzolódhat a tervezés adott kontextusban értelmezett társadalmi funkciója:

1. Hogyan értelmezzük a valóságot?

2. Mi a szerepe a tervnek a valóság formálásában?

3. Mi a tervezés értelmezési tartománya?

4. Kik a szereplói, és ezek milyen szervezeti rendszerben vesznek részt a folyamatban?

5. Mi a célnak megfelelố tervezési módszer?

Úgy vélem, ezekból a kérdésekból két fontos tanulság bontakozhat ki:

A) Egy tervezési paradigma következetességéhez fontos a tervező közremúködése és szakértelme, a tervezés rendszerének meghatározó elemei azonban alapvető́n társadalmi döntéseken nyugszanak, vagyis ezek tisztázása szigorúan közügy!

Ha ugyanis végignézzük a tervezési paradigmák szerkezetét boncoló kérdéseket, akkor azt láthatjuk, hogy itt nem elsôsorban absztrakt tudományos tevékenységgel, hanem a tervezési folyamat értelmezési tartományát alkotó közösség értékválasztásainak sorozatával állunk szemben. A tervezés folyamatában értelmezett „valóság” komplex ingerhalmaza önmagában is végtelen számú tömörítési eljárással értelmezhetô és értékelhetô, amelyek közül a legitim módszer kiválasztása társadalmi közmegegyezés tárgya és alapvetően kulturális kérdés. (Egyébként végsố soron az így kialakuló értékrend a kulcsa annak is, hogy a tervezés eredményét és sikerességét mérhetôvé tegyük.)

${ }^{9}$ A téma alapmüve Susan F. Fainstein - Scott Campbell: Readings in Planning Theory. 2003. 
Ugyanakkor a tervezési folyamat szereplôinek kiválasztása, a szerepek megfogalmazása és a közösségre érvényes viselkedési normák meghatározása is közmegegyezés kérdése, és alapjában véve az elóbbiekhez hasonlóan a közösségi kultúrából fakad.

B) A mi szempontunkból azonban talán még fontosabb - és tulajdonképpen az elôzó pontból következik -, hogy a tervezési folyamat sikeressége hallatlanul érzékeny a társadalom legtágabban értelmezett kultúrájának minden változására.

Ha ugyanis nincs közmegegyezés a tervezés társadalmi szerepéról, akkor a tervezés legitimitási válságba jut, ha pedig a társadalom kulturális válságban van, vagyis értékrendje drasztikus átalakuláson megy keresztül, vagy nincs megfelelő eszköz, amellyel az adott kulturális közeg elvárásai a tervezés számára kikristályosíthatók lennének, akkor a tervezés értékválságba kerül. A tervezés folyamata - bár különböző módokon - mindkét esetben ellehetetlenedik, mert a közmegegyezés hiánya a tervezési folyamat irányítóképességének megszúnését jelenti, a kulturális zavarok pedig a terv céljának megfogalmazását és eredményességének értelmezését egyaránt lehetetlenné teszi. Ahhoz tehát, hogy a tervezés sikeresen töltse be társadalmi küldetését, minden jelentốs társadalmi változás alkalmával újra kell építenünk a konszenzust a tervezés szerepéról és értékrendjéról, vagyis újra kell definiálnunk a tervezés fogalmát és egész rendszerét. Egyébként a társadalmi átalakulási folyamatok sikeressége vagy sikertelensége nagyszerűen vizsgálható éppen a tervezési folyamatok minőségének a tükrében, s ugyanakkor - érdekes módon - ugyanezek a tervezési folyamatok egyúttal eszközei, katalizátorai is lehetnek egy ilyen szerkezetváltásnak.

\section{A tervezés helyzete a rendszerváltás utáni Magyarországon}

Az olvasót feltehetôen nem lepem meg, amikor azt állítom, hogy a rendszerváltáskor megindult politikai decentralizáció, valamint az „információs társadalom” kialakulásával jellemezhetô társadalmi paradigmaváltás ${ }^{10}$ minôségi változást hozott magával a tervezés közegében is. Nem váratlan az sem, ha egy ilyen változás ahhoz vezet, hogy szükségszerúen át kell értékelnünk a tervezés fogalmát és végrehajtásának folyamatát egyaránt. Magyarországon a tervezés rendszere döntốen ennek a két tényezônek tulajdoníthatóan került egyszerre legitimitási és értékválságba, melynek jelei jól kirajzolódnak mind a tervezés gyakorlatában, ${ }^{11}$ mind a nagy városfejlesztési tervek sorsában. ${ }^{12}$ Fontos tudnunk azonban, hogy mindez nem a tervezés általános válságát jelenti, hanem a tervezésnek csak az a - közgondolkodásban is megcsontosodott - ,tervhivatali”

${ }^{10}$ Azért ezt a két tényezöt említem, mert úgy gondolom, hogy ezek következményeinek kibontásával magyarázható a hazai jelenségek java része.

"Az épitészet jogi környezetének anomáliáiról és az építészet társadalmi helyzetéröl aktuális és nagy port kavart vita bontakozott ki Ertsey Attila kiváló cikke nyomán, amely itt olvasható: http://cpiteszforum.hu/ node/10943

${ }^{12}$ Lásd például Gauder Péter éleslátással megfogalmazott kritikáját a Budapest 2010 Kulturális Főváros pályázatáról: http://epiteszforum.hu/node/272, http://epiteszforum.hu/node/270. Egy másik ,állatorvosi lóként” ennek a párját, a Pécsi Kulturális Főváros programot emlithetjük, amclyröl rengeteg érdekes írás jelent meg, én azonban itt a pályázat szellemi vezctöjével, Takáts Józseffel készült interjút emelnćm ki: http://epiteszforum.hu/ node/2439 
értelmezése bizonyul sikertelennek, amely mind a mai napig alapjaiban határozza meg a hazai tervezési kultúrát, és amelynek a kudarcaival napról napra szembesülhetünk.

A fent említett modern és az Alexander által megfogalmazott posztmodern tervezési paradigmák között feszülő́ ellentét ugyan nem teljes mértékig magyarázza meg a hazai válságjelenségeket, de mindenképpen hasznos tanulságokkal szolgál az átalakulási folyamat kihívásainak megértéséhez. Minél többet olvasok a témáról, és minél többet töprengek ennek a szerkezetváltásnak a dilemmáin, annál inkább kezdem úgy látni, hogy a jelenségek bizonyos tanulási folyamat körül csoportosulnak.

Tanulási folyamatról van szó, hiszen egy új tervezési kultúra meghonosítása, a szereplók új szerepeinek az elsajátítása önmagában is tanulást igényel. Ha a magyarországi szakirányú képzés rendszerét összehasonlítjuk például az angolszász egyetemek gyakorlatával, ${ }^{13}$ jól látszik, hogy a tervezônek milyen új készségeket kell elsajátítania ahhoz, hogy a folyamatosan átalakuló tervezési közegben eredményesen irányíthassa a tervezés folyamatát. Fontos megjegyezni itt, hogy politikailag decentralizált tervezési közegben nem elég, ha a tervezó ,jól játssza a szerepét”, hiszen a tervezési folyamatban számos szereplönek van döntéshozatali jogköre. Ezért a tanulási folyamatban a tervezók mellett, velük egyidejúleg részt kell vennie a tervezés többi szereplójének is. Ilyen közegben a tervezési kultúra kialakulása csak bizonyos mértékig vezethetố vissza a közpolitikai centrum döntéseire, sokkal inkább a centrum és a decentrumok közötti dialógus során megvalósuló közös tanulási folyamat útján jön létre. Egy ennyire gyors ütemben változó társadalomban, amilyen a miénk, nem lehet olyan fix pontokat találni, amelyekre hosszabb távon sikeres társadalmi konszenzust lehetne építeni a tervezés szerepéról, vagyis a tervezési folyamat sikerességét az állandóan változó tervezési közegben csakis kölcsönös tanulás biztosíthatja.

A jelenlegi hitelválság kapcsán fel kell tennünk azt a kérdést is, hogy létezik-e egyáltalán ma olyan minta vagy külföldi példa, melyet a hazai tervezési kultúránk formálásában követhetünk: sajátos helyzetünkból adódóan úgy túnik, hogy a szóban forgó tanulási folyamat csak korlátozottan lehet „eltanulás”. Fontos megjegyeznünk továbbá, hogy a tervezési kultúra fejlődésében ugyan számos általánosnak túnố jelenség - például a globalizáció, a politikai decentralizálódás vagy a hálózati társadalom kialakulása - tapasztalható Magyarországon is, de egyre növekvő számú összehasonlító nulmány ${ }^{14,15}$ és a tervezéselmélet fejlődésének iránya ${ }^{16}$ is azt sugallja, hogy ezek csak igen korlátozott mértékben képesek magyarázni a lokális tervezési kultúra változásait.

${ }^{13}$ Vö. például www.bartlett.ucl.ac.uk

${ }^{14}$ Susan Fainstein: Can we make the city we want? In R. Beauregard - S. Body-Gendrot - L. Beauregard (eds.): The Urban Moment: Cosmopolitan Essays on the late 20th Century City. 1999, Sage Publications. E tanulmányában a szerző többck között a globalizáció jelensćgćt vizsgálja három crösen cltérö tervezćsi kultúrájú „globális város”, New York, London ćs Amszterdam összchasonlitásával.

15 Bishwapriya Sanyal (ed.): Comparative Planning Cultures. 2005, Routledgc. A szcrkesztö a világ tíz különbözö tervezési kultúráját mutatja be egy-egy tervezési szakember tolmácsolásában, azzal a szándékkal, hogy igazolja vagy cáfolja az cltérő tervezési kultúrákban alkalmazott tervezési paradigmák közötti hipotetikus összefüggéseket vagy különbségeket.

${ }^{16}$ Gloria Anzaldúa: La Frontera/Borderlands. 1999, Aunt Lute Books. A szerző a posztmodern radikális tervezési paradigma egyik karizmatikus figurája. Számára a tervezés alapvetően kulturális tevékenység, amely a valóság különböző narratíváiból fakad. Ebböl a nézöpontból a tervezés jelenségei csak olyan mértékben általánosithatók, amilyen mértékben az érintett kultúrák átfedik egymást. 
A fentiekból az következik, hogy ma Magyarországon nem klasszikus értelemben vett új tervezési politikát kell kidolgozni vagy meghonosítani, hanem egy tanulási folyamatot kell szorgalmazni, és elôsegíteni a tervezés szereplốinek teljes spektrumában, aminek eredményeként új és várhatóan hosszabb időn keresztül további megújulásra képes tervezéspolitika alakulhat ki. Ez a közös tanulás pedig bizonyosan eredménytelen lesz, ha csak az építészet ügye marad, és nem sikerül mozgósítani a releváns ismereteket nyújtó valamennyi tudományág képviselóit is. 